\title{
The Characterization of Ditylenchus Gigas, N.Sp in the Biskra Region
}

\author{
Saadi Ines, Boumaraf Belkacem and Saadi Hacina
}

\begin{abstract}
Nematologists need proper identification of species for research, education, protection and other activities. Therefore, identification of nematodes must be more and more accurate. For this, the nematode strains must be identified using morphometric measurements. In Algeria the identification of the genus Ditylenchus is based only on the morphological aspect. For the first time in Algeria, 8 characteristic biometric criteria commonly used to define species of the genus were realized.

The results obtained give typical morphological characters for this nematode collected in a specific climatic zone with great potential for bean culture (Vicia faba) which would imply a new approach and research for a more appropriate integrated control.
\end{abstract}

Keywords: Ditylenchus gigas, Vicia faba, Nematodes, morphometrics Algeria.

\section{INTRODUCTION}

Ditylenchus gigas, is an obligate endoparasite mainly found in the stems and leaves of infested plants. It is considered in Algeria and globally as a limiting factor in the development of legume and especially bean crops (Esquibet et al., 1998, Sellami et al, 1998, Esquibet et al., 2003 in Saadi, 2008).

In Algeria, the presence of this nematode was reported for the first time by Debray and Maupas in 1896, this species is still considered the most formidable bean. is present in almost all bean plots in all areas of the country, it remains a serious threat to this crop (Di Vito et al., 1994, Sellami et al, 1996, Sellami et al, 1998, Saadi, 2008). ).

The European and Mediterranean Plant Protection Organization (EPPO) has listed D. dipsaci as an A2 quarantine pest in many countries in this region (EPPO, 2009). This nematode easily withstands sub-zero temperatures in winter, and soil temperature up to $55^{\circ} \mathrm{C}$ in summer, and even for decades. It can be isolated even from completely dry plant material after moistening (Sturhan et al, 1991). This nematode of the stem and bulb is an endoparasite of the higher plants that feeds in the parenchymal tissues of the stem of about 500 plant species, causing growth retardation and swelling and significant deformities of the plants (Sturhan and al, 1991).

Dr Saadi inesse, University of Biskra , Algeria

Boumaraf Belkacem, University of Biskra, Algeria

Saadi Hacina, University of Biskra, Algeria
It has been pointed out by many authors that D. gigas consists of a number of breeds and populations whose host preferences at different stages of biological reproductive speciation offer variances, representing a different species status (Sturhan et al 1991). After phylogenetic analysis of rDNA sequences of genes from different populations and breeds (Subbotin et al., 2005) confirmed that Ditylenchus dipsaci represented a complex of species, which comprises at least seven species, while other species are not not yet properly studied and described.

Only D. dipsaci sensu stricto and Ditylenchus gigas. Infecting the beans, known as the "giant race" of the stem nematode, is of economic importance as a plant parasite (Sikora and Greco, 1990) and (volvas et al, 2011).

The giant stem nematode breed was recorded as a serious bean disease in several European and African countries bordering the Mediterranean Sea and in Iran in 2013. In addition, several authors have noted that the giant breed is generally more damaging because it causes more severe symptoms in the bean field than any other D. dipsaci breeds and produces more infested seeds, despite the fact that it appears to have a limited range of hosts (Goodey 1941, Hooper 1971, Sikora et al. al, 1990, Sturhan et al 1991, volvas et al 2011, Tanha et al 2013). Several detailed studies conducted with a giant breed population have shown that this breed is also distinguished from the normal breed in its biology.

The normal race is thought to have a diploid number of $2 \mathrm{n}=$ 24 chromosomes, whereas the giant borer-parasitic breed is tetraploid at 2n = 48-60 (Sturhan, 1969, 1970, D'Addabbo et al., 1982, Sturhan et al, 1991 Volvas et al, 2011Tanha et al 2013).

Crossing experiments with diploid races D. dipsaci stricto sensu and the giant breed showed that F1 hybrids were formed, but they were sterile. These results led Sturhan (1983) to conclude that the giant breed should therefore be recognized as a distinct species.

Accurate detection and identification of Ditylenchus species as well as knowledge of the pathogenic variability of populations in the field is crucial for regulatory control of control, as well as for the reproduction and development of resistant cultivars (Mahfouz et al. 2014) In the present study, on nematodes isolated from Ditylenchus gigas individuals collected on areas with high potential for bean culture (Vicia faba) is a first unpublished and precise characterization of this 
breed in Algeria using a morphological approach. metric. The new species of nematodes are described here as Ditylenchus gigas n. sp. Based on the analysis of several populations collected from beans in an arid region in southeastern Algeria (Biskra).

\section{MATERIALS AND METHODS}

\section{A. Sampling and extraction of nematode populations}

After prospecting on several sites of bean cultures in the regions of Biskra (located in the south-east of Algeria in an arid climatic zone) presenting the symptoms of nematode infection, namely brown and reddish necroses, which black and begin at the collar, and extend over the entire stem. Foliage and flower discolouration, plant malformation and distortion, and shortening of internodes (Stuteville et al., 1990, Caubel and Esquibet, 1995). Samples were taken from several plots. In the laboratory the stems are washed to remove soil and adhering debris. Subsequently the plant tissues are cut into pieces of $\sim 2 \mathrm{~cm}$ with a pair of scissors and placed in the bottom of a Petri dish with a little water for immediate observation, after having previously torn the tissues of the plant with needles and forceps to release tissue nematodes. After 5-6 h, the nematodes that emerged are used for morphological observations.

\section{B. Morphological examination}

For diagnosis and identification, the nematodes were extracted by soft heat narcosis, and mounted in agar (Esser, 1986). Adult specimens were also treated in glycerol in permanent fixtures, according to the method of Seinhorst (1966), the morpho-diagnostic examination was carried out using a $35 \mathrm{~mm}$ camera mounted on a microscope composed Reichart (Reichart-Jung ) equipped with an optical contrast contrast (DIC) differential. The measurements were calculated using software provided with the microscope (Leica Application Suite (LAS)) which allowed us to perform 14 morphometric measurements for each nematode.

\section{RESULTS AND DISCUSSION}

Giant specimens collected in the Biskra area cause severe swelling and deformation of the stem tissue in the bean, and lesions that turn reddish-brown and then black. The lesions of the stem wrapped and increased in length (from 0 to $8 \mathrm{~cm} 2$ ), often reaching the edge of an inter-node. Necrotic petioles were also evident, which can be confused with the symptoms induced by fungal leaf pathogens. In this advanced stage of infection, the seeds, which were also infected with the nematode, appeared darker, deformed, smaller in size and with speckles like on the surface. Serious infections often kill the main shoots, and stimulate the formation of secondary bars.

\section{A. The morphometric results}

TABLE I: MORPHOMETRICS (FEMALES AND MALES) OF DITYLENCHUS GIGAS N.SP EXTRACTED FROM VICIA FABA IN THE REGION OF BISKRA

\begin{tabular}{|l|c|c|}
\hline & Femelles & Mâles \\
\hline $\mathrm{N}$ & 20 & 18 \\
\hline $\mathrm{L}^{\mathrm{b}}$ & $1815.9 \pm 82.9(1653-1927)$ & $1624.7 \pm 107.6(1462-1947)$ \\
\hline Stylet length le stylet & $12.2 \pm 0.4(11.5-12.9)$ & $11.6 \pm 0.5(10.7-12.4)$ \\
\hline V or T(\%) & $84.2 \pm 1.0(81-87)$ & $73.4 \pm 8.1(62.3-85.7)$ \\
\hline Pharynx (to end of gland lobe) & $240.2 \pm 3.2(234-245)$ & $212.7 \pm 7.9(200-226)$ \\
\hline Vulva-anus distance & $230 \pm 21.1(201-264)$ & - \\
\hline PUS & $132 \pm 14.5(96-157)$ & - \\
\hline Tail length & $88.2 \pm 6.5(76.1-98.7)$ & $82.2 \pm 6.7(72.6-91.2)$ \\
\hline Spicule length & - & $25.3 \pm 1.5(22.9-27.7)$ \\
\hline A & $42.2 \pm 2.2(38.6-46.0)$ & $42.2 \pm 2.2(39.2-46.8)$ \\
\hline B & $8.1 \pm 0.4(7.3-8.6)$ & $8.1 \pm 0.6(7.0-9.2)$ \\
\hline$b^{\prime}$ & $7.5 \pm 0.3(6.9-8.1)$ & $7.6 \pm 0.6(6.7-8.9)$ \\
\hline C & $20.7 \pm 1.8(17.7-24.1)$ & $19.9 \pm 2.1(16.4-23.5)$ \\
\hline$c^{\prime}$ & $4.8 \pm 0.7(3.4-6.6)$ & $4.6 \pm 0.6(3.8-5.6)$ \\
\hline
\end{tabular}

\section{The morphometric results Female:}

The number of subjects analyzed in the Biskra region and 20 nematodes total length for females is $1815.9 \pm 82.9 \mu \mathrm{m}$. These averages are relatively larger than those obtained by 
Volvas et al in 2011 in the three regions of the Mediterranean basin (Italy, Lebanon and Spain). The morphological and morphometric characteristics were in agreement with those published by Tanha et al 2013 and Volvas et al in 2011. Similarly for the stylet length which is $12.2 \pm 0.4 \mu \mathrm{m}$ (see Figure $1(a, b, h)$.

The distance from the pharynx to the end of the lobe glans are in the order $240.2 \pm 3.2 \mu \mathrm{m}$. From the head to the anus (excretory pore) the values are $162 \pm 17.2 \mu \mathrm{m}$. For the ovular cyst ,. The distance from the vulva to the anus is in the order of $230 \pm 21.1 \mu \mathrm{m}$ (see Figure 1 (b)). Finally the length of the tail we found $88.2 \pm 6 . .5 \mu \mathrm{m}$ of Biskra (see Figure $1(\mathrm{~g})$ ).

\section{The morphometric results Male:}

The number of males studied in the two regions are 20 nematodes the average total length of the male is $1524.7 \pm$ $107.6 \mu \mathrm{m}$, all morphological characteristics relatively similar to those of the female, except in the reproductive system. Slightly narrower than the rest of the body (Tanha et al 2013 and Volvas et al in 2011). The length of the stylet is $12.2 \pm 0.4$ $\mu \mathrm{m}$ (see Figure $1(\mathrm{a}, \mathrm{c}, \mathrm{h})$.) The pharynx at the end of the glans lobe are in the order $212.7 \pm 7.9 \mu \mathrm{m}$ From the head to the anus the values are from $153 \pm 13.8$ and $160 \pm 12.3 \mu \mathrm{m}$, the length of the spicule raises it and $25.3 \pm 1.5$.

TABLE II. MORPHOMETRY OF FEMALES AND MALES OF DiTYLENCHUS GIGAS N. SP. OF VICIA FABA A (NOCI, BARI, SOUTHERN ITALY) (VOLVAS ET AL 2011)

\begin{tabular}{|l|l|l|}
\hline \multirow{2}{*}{$n$} & Les femelles & Mâles \\
\cline { 2 - 3 } & Moyenne \pm SD (plage) & Moyenne \pm SD (plage) \\
\hline$L^{\mathrm{b}}$ & 20 & 12 \\
\hline Longueur du stylet & $1780 \pm 97.4(1561-1932)$ & $1557 \pm 98.2(1373-1716)$ \\
\hline V ou $T(\%)$ & $12.0 \pm 0.4(11.5-13.0)$ & $11.6 \pm 0.4(11.0-12.5)$ \\
\hline Tête au centre de métacorpus & $81.5 \pm 1.0(80-83)$ & $72.4 \pm 11.7(57.6-100)$ \\
\hline Pharynx (à cardia) & $77 \pm 4.3(65-83)$ & $75 \pm 7.8(58-88)$ \\
\hline Pharynx (à la fin du lobe de la glande) & $206 \pm 11.1(191-228)$ & $192 \pm 25.8(143-218)$ \\
\hline Tête vers les pores excréteurs & $212 \pm 11.8(194-236)$ & $198 \pm 26.4(148-223)$ \\
\hline Spermathèque longueur & $158 \pm 18.6(108-179)$ & $153 \pm 14.8(124-173)$ \\
\hline Vulva-anus distance & $127,5 \pm 22,9(98-176)$ & - \\
\hline PUS & $228 \pm 20.1(202-266)$ & - \\
\hline Longueur de queue & $120 \pm 16.4(81-150)$ & - \\
\hline Corps anal diam. & $88,5 \pm 12,6(69-103)$ & $87.3 \pm 6.5(74-96)$ \\
\hline Longueur du spicule & $18.5 \pm 2.4(15.0-21.5)$ & $16.8 \pm 1.3(15.0-19.5)$ \\
\hline Gubernaculum & - & $25.4 \pm 1.2(23.5-28)$ \\
\hline$A$ & - & $8.8 \pm 0.8(8.0-10.0)$ \\
\hline$b$ & $48.9 \pm 3.9(43.0-56.4)$ & $56.7 \pm 7.6(34 \cdot 3-63.0)$ \\
\hline$b^{\prime}$ & $8.5 \pm 0.5(7.3-9.3)$ & $8.3 \pm 1.3(6.7-10.7)$ \\
\hline$c$ & $8.3 \pm 0.6(7.3-9.2)$ & $8.0 \pm 1.3(6.5-10.4)$ \\
\hline$c^{\prime}$ & $20.0 \pm 3.2(16.8-27.6)$ & $17.9 \pm 1.2(15.7-20.0)$ \\
\hline
\end{tabular}

a All measurements are in $\mu \mathrm{m}$ unless otherwise indicated.

b All other abbreviations used are defined by Siddiqi (2000)

\section{Synthesis of morphometric results}

The gigas n.sp.se breed differs from all other Ditylenchus on several morphological characteristics. Major diagnostic character and body length.

Indeed, the results obtained on the length of the nematodes obtained $1815.9 \pm 82.9 \mu \mathrm{m}$ (1653-1927) for female nematodes $1624.7 \pm 107.6 \mu \mathrm{m}$ (1462-1947) for males clearly indicate higher values than those quoted by Volvas et al 2011 ( Table: 03 and 04) at Noci, Bari Itali (1780 $\pm 97.4 \mu \mathrm{m}$ (1561-1932) for females1557 $\pm 98.2 \mu \mathrm{m}$ (1373-1716) for males) Other distinguishing parameter and distance from vulve- anus or results obtained by Tanha (2013) and $217 \pm 21.0 \mu \mathrm{m}$ (178272) against $268 \pm 32.8 \mu \mathrm{m}(201-264)$.

Also for the stylet length or the results obtained by Volvas et al 2011 (Table: 03 and 04) and $12.0 \pm 0.4 \mu \mathrm{m}$ (11.5-13.0) for females and of $11.6 \pm 0.4 \mu \mathrm{m}$ (11.0-12.5) for females. males against nematodes from the Biskra region 12.2 $\pm 0.4 \mu \mathrm{m}$ (11.5-12.9) for female subjects and $11.6 \pm 0.5 \mu \mathrm{m}$ (10.7-12.4) for male subjects. 
TABLE III. PRINCIPALES CARACTÉRISTIQUES MORPHOMÉTRIQUES DIAGNOSTIQUES D'AUTRES POPULATIONS DE DitYLENCHUS GIGAS N. SP. DE VICIA FABA CITÉ PAR VOLVAS ET AL 2011

\begin{tabular}{|c|c|c|c|}
\hline & $\begin{array}{c}\text { Beyrouth, vallée de la } \\
\text { Bekaa, Liban }\end{array}$ & $\begin{array}{c}\text { Córdoba (province de } \\
\text { Córdoba) Espagne } \\
\end{array}$ & $\begin{array}{c}\text { Ostuni (province de } \\
\text { Brindisi), Italie } \\
\end{array}$ \\
\hline & Moyenne \pm SD $($ plage $)$ & Moyenne \pm SD (plage) & Moyenne \pm SD $($ plage $)$ \\
\hline$N$ & 6 & 5 & 5 \\
\hline$L^{\mathrm{b}}$ & $1640 \pm 52(1560-1690)$ & $1789 \pm 101.8(1657-1903)$ & $1806 \pm 84 \cdot 4(1687-1924)$ \\
\hline Longueur du stylet & $11.5 \pm 0.6(10.5-12 \cdot 0)$ & $12.5 \pm 0.5(12.0-13.0)$ & $12 \cdot 1 \pm 0 \cdot 5(11 \cdot 5-13 \cdot 0)$ \\
\hline$V(\%)$ & $82.0 \pm 1.0(80-83)$ & $81.8 \pm 1.3(80-83)$ & $81 \cdot 6 \pm 0 \cdot 9(81-83)$ \\
\hline PUS & $94 \pm 6.9(85-101)$ & $123 \pm 19.0(102-145)$ & $119 \pm 18.7(98-148)$ \\
\hline Longueur de queue & $84.0 \pm 5.6(77-91)$ & $95.0 \pm 3.9(89-99)$ & $97.0 \pm 5.7(87-101)$ \\
\hline $\begin{array}{l}\text { Longueur du } \\
\text { spicule }\end{array}$ & $25.5 \pm 0.8(24.5-26.0)$ & $25.0 \pm 1.0(24-26)$ & $24.8 \pm 0.8(24-26)$ \\
\hline Une & $51.7 \pm 2.6(48.0-54.0)$ & $44.3 \pm 2.9(40.4-47.7)$ & $45.4 \pm 2.1(42.8-48 \cdot 1)$ \\
\hline$b^{\prime}$ & $8.1 \pm 0.5(7.7-8.5)$ & $8.8 \pm 0.3(8.4-9.0)$ & $8.6 \pm 0.3(8.3-9.1)$ \\
\hline$C$ & $19.5 \pm 1.3(17.5-21.0)$ & $18.8 \pm 0.6(18.2-19.6)$ & $18.6 \pm 0.7(18.0-19.4)$ \\
\hline$c^{\prime}$ & $5.1 \pm 0.5(4.8-5.4)$ & $4.6 \pm 0.3(4.1-4.8)$ & $5.0 \pm 0.5(4.4-5.6)$ \\
\hline
\end{tabular}

a All measurements are in $\mu \mathrm{m}$ unless otherwise indicated.

b All other abbreviations used are defined by Siddiqi (2000)

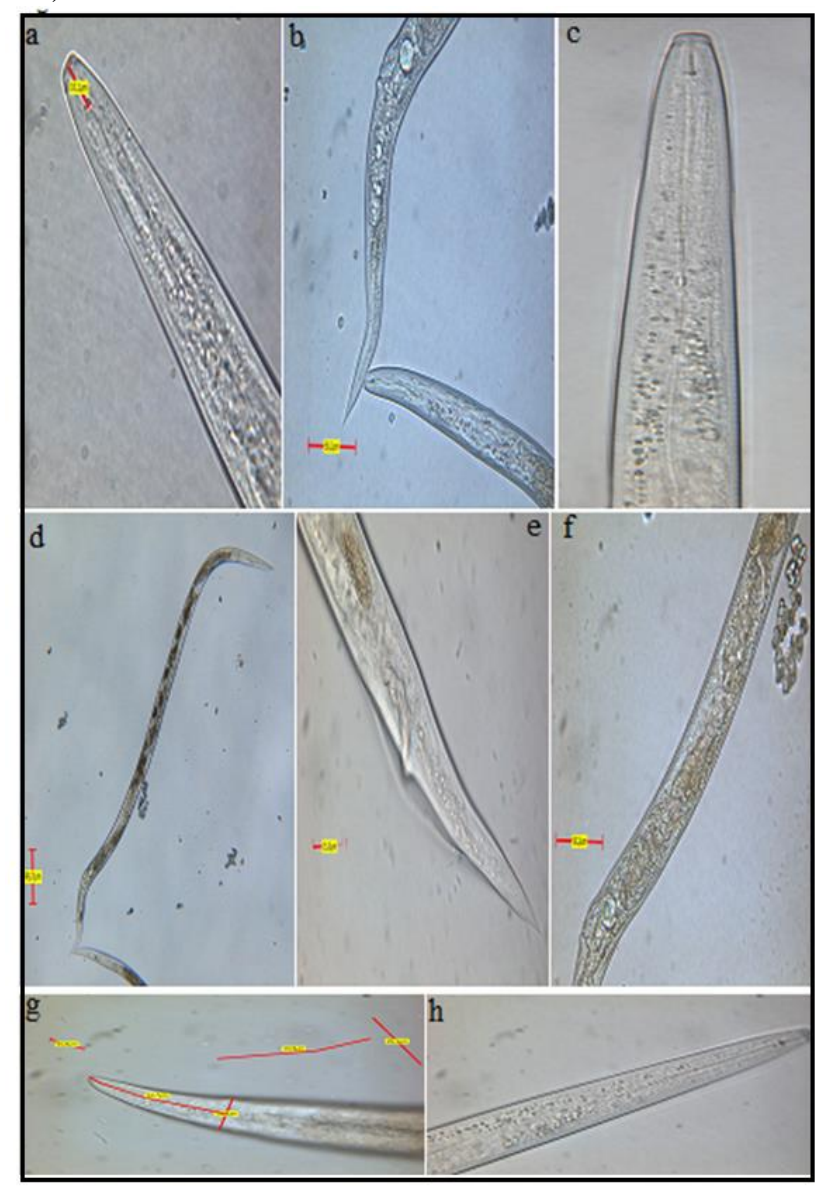

Fig. 1

at. measuring the stylus of $\mathrm{D}$ gigas b.posterior portion of female cC. metacorpus, stylet d. femalel Ditylenchus gigas e.posterior spicule of male portion, $f$ Vulve, Spermatheca.g Measurement of Tail of nematode, metacorpus h, stylet

The vulva anus distance at higher values for nematodes from Biskra populations respectively $230 \pm 21.1 \mu \mathrm{m}$ (201-264) than that by Tanha et al 2013 in Iran $217.0 \pm 21.0 \mu \mathrm{m}(178$ 272) and almost the same similarities for the tail. Similar observations for spicule length from the data cited by Volvas et al 2013 in Beka, Lebanon with $25.5 \pm 0.8 \mu \mathrm{m}$ (24.5-26.0) and Cordoba in Spain with $25.0 \pm 1.0 \mu \mathrm{m}$ (24-26). and finally in Ostuni in Italy with $24.8 \pm 0.8 \mu \mathrm{m}$ (24-26) against $25.3 \pm$ $1.5 \mu \mathrm{m}(22.9-27.7)$ in Biskra

In view of Tables 3 and 4 the collected parameters cited by Volvas et al 2011 and Tanha et al 2013 demonstrate the set of characters studied approach and define the individuals collected on Vicia faba in Biskra as Ditylenchus gigas.

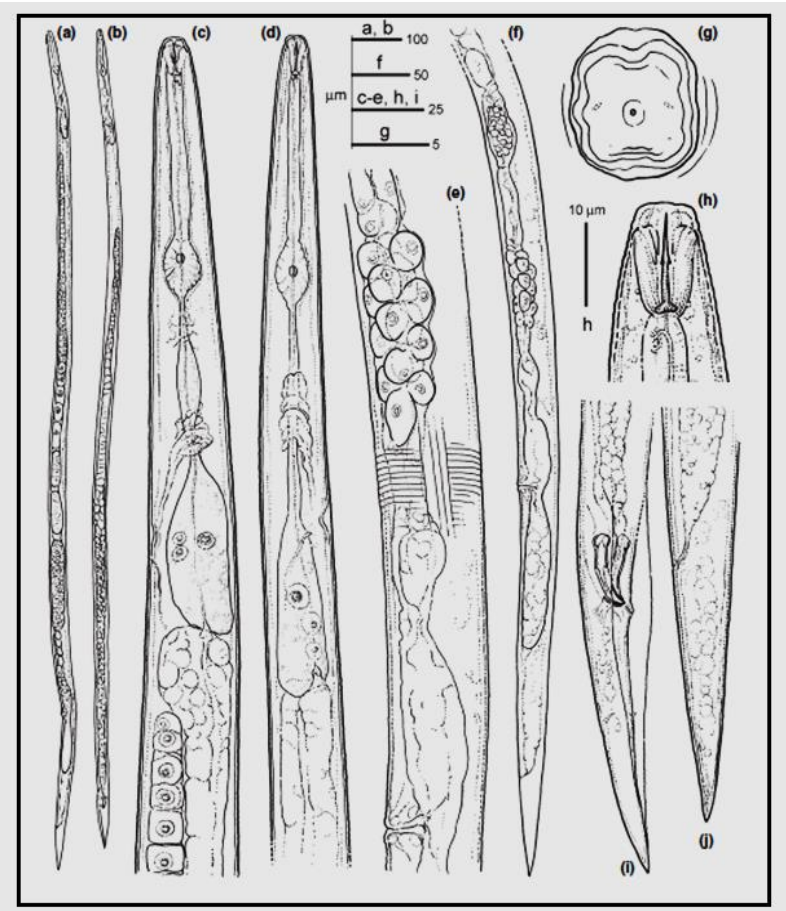

Fig. 2

: Schemas of the different parts of Ditylenchus gigas.n.sp, (a) female (b) male all the body (b)

\section{CONCLUSION}

Stem and bulb nematodes in a Ditylenchus species complex are endoparasites, which attack a wide range of crops and cause stunting and swelling, causing significant economic 
losses (Madani et al 2015 ). It is considered in Algeria and at the global level as a limiting factor in the development of legume and especially bean crops (Esquibet et al., 1998, Sellami et al, 1998 and Esquibet et al, 2003).

Several authors have suggested that D.dipsaci is a set of races (comprising at least 7 races) and in particular, that the "giant race" should be considered as a distinct taxon. In Algeria The Ditylenchus genus is traditionally identified with general typological morphology because in this population, adult nematodes were considerably larger than those currently observed, making breed recognition a very difficult task (Sturhan et al, 1991). This breed has damage that differs from that caused by D. dipsaci stricto sensu in a heavier distribution across the main stem, leaves and pods, and in the highest percentage of infected seeds, which could be of concern (Hooper 1984 in Esquibet, 1998)

The description of nematode species is particularly. The giant race of Ditylenchus dipsaci is based on morphometric and morphological records, which was obtained for the first time in Algeria with these types of measurements from populations of $\mathrm{D}$. dipsaci collected on $\mathrm{V}$. faba in the region of Biskra and which corroborate with those obtained in southern Italy and Spain and Lebanon, Vovlas et al. (2011) and finally in Iran in 2013 (Tanha et al 2013).

\section{REFERENCES}

[1] -Castillo P , Vovlas N, Subbotin S, Trocoli A, 2003 . Un nouveau nématode cécidogène, Meloidogyne baetica $n$. sp. (Nematoda: Heteroderidae), parasitant l'olive sauvage dans le sud de l'Espagne . Phytopathologie 93 , 1093 - 102 . et al. (2003) https://doi.org/10.1094/PHYTO.2003.93.9.1093

[2] -Cauble.G.,Esquibet.M., 1995- Le nématodes des tiges en culture de légumineuses., Phytoma La défense des végétaux., $\mathrm{N}^{\circ} 476$ Octobre.,pp. 25-30

[3] -Debray F, Maupas EF, 1896. Le Tylenchus devastatrix Künh et la maladie vermiculaire des fèves en Algérie. Algérie Agricole, $55 \mathrm{p}$.

[4] -Di vito M ;Greco N.; Halila H.M. ; Mabsoute L. ; Labdi M. ; Beniwal s Et solh, m.b.1994.Nematodes of cool season food legumes in North Africa Nematol. medit. 22 : 3-10;

[5] -Esquibet M., Grenier E., Plantard O., Abbad Andaloussi F., Caubel G. (2003): DNA polymorphism in the stem nematode Ditylenchus dipsaci: development of diagnostic markers for normal and giant races. Genome, 46: 1077-1083 https://doi.org/10.1139/g03-072

[6] -Esquibet M., Bekal S., Castagnone-Sereno P., Gauthier J.P., Rivoal R., Caubel G. (1998): Differentiation of normal and giant Vicia faba populations of the stem nematode Ditylenchus dipsaci: agreement between RAPD and phenotypic characteristics Hérédité 81 , 839 - 50 . https://doi.org/10.1046/j.1365-2540.1998.00367.x

[7] -Esser RP , 1986 . A water agar en face view technique. Proceedings of the Helminthological Society of Washington 53, 254-.

[8] -Goodey T, 1941. Observations on a giant race of the stem eelworm Anguillulina dipsaci, attacking broad beans, Vicia faba L. Journal of Helminthology 19, 114-22.
[9] -Hooper DJ, 1971. Stem eelworm (Ditylenchus dipsaci), a seed and soil-borne pathogen of field beans (Vicia faba). Plant Pathology 20,25-7. https://doi.org/10.1111/j.1365-3059.1971.tb00502.x

[10] -Hooper DJ , 1984 . Observations sur le nématode de la tige, Ditylenchus dipsaci, haricots attaquants, Vicia faba . Rapport de la station expérimentale de Rothamsted pour 1983, 239 - 60

[11] -Mahfouz M. M. Abd-Elgawad ;2014: Yield losses by Phytonematodes: challenges and opportunities with special reference to Egypt. Egypt. J. Agronematol., Vol. 13, No.1, PP. 75-94 (2014)

[12]-OEPP,2009 Liste A1 et A2 des organismes nuisibles recommandés pour la réglementation en tant qu'organismes de quarantaine $\quad$ En ligne [http://www.eppo.org/QUARANTINE/quarantine.htm ].

[13] -Saadi, I 2008) Analyse des semences de fève (vicia faba infestées par Ditylenchus dipsaci (Nematode; Anguinidae) et recherche d'une méthode de lutte contre ce nématode. Thèse de magister 72 P ENSA ,El Harrach Alger..

[14] -Sellami S.,Bousnina Z , et Bacha F., 1998. Nématofaune associée à la fève et plante -hôtes du nématode des tiges : Ditylenchus dipsaci Kuhn ( Filipjev). Dans ACTES: Sémin Nat sur légumineuses alimentaires à Ain Temouchent. 211-218.

[15] -Sellami S., et Bousnina Z., 1996 . Distribution de Ditylenchus dipsaci (Kuhn) Filipjev 1936 dans l'Est Algerien. Réhabilitation of Faba bean, Ed. Actes Rabat (Maroc). 202p

[16] -Siddiqi MR, 2000. Tylenchida Parasites of Plants and Insects. 2nd edition. Wallingford, UK: CABI Publishing. 848 Pages / ISBN0851992021 https://doi.org/10.1079/9780851992020.0000

[17] -Sikora RA et Greco N, 1990; Nematode parasites of food legumes. . Plant Parasitic Nematodes in Subtropical and Tropical Agriculture. Wallingford, UK: CAB International, 181-235.

[18] -Sturhan D, Brzeski MW, 1991. Stem and bulb nematodes, Ditylenchus spp. In: NickleWR, ed. Manual of Agricultural Nematology. New York, USA: Marcel Dekker, 423-64.

[19] -Stuteville, D. L, and ErY\Tin, D. C. (eds.) 1990. Compendium of alfalfa disease, 2nd ed. APS press. St Paul, MN.

[20] -Subbotin SA, Madami M, Krall E, Sturhan D, Moens M, 2005. Molecular diagnostics, taxonomy and phylogeny of the stem nematode Ditylenchus dipsaci species complex based on the sequences of internal transcribed spacer-rDNA. Phytopathology $95,1308-15$ https://doi.org/10.1094/PHYTO-95-1308

[21]-Tanha Maafi Z and Majd Taheri Z, First Report of the Giant Stem Nematode, Ditylenchus gigas, from Broad Bean in Ira PLANT DISEASE. July 2013, Volume 97, Number 7 Pages $1,005.3-1,005.3$ https://doi.org/10.1094/PDIS-01-13-0069-PDN

[22] Vovlas N, A. Troccoli, J. E. Palomares-Rius, F. De Luca, G. Lie'banas, B. B. Landa, S. A. Subbotin and P. Castillo. 2011: Ditylenchus gigas n. sp. parasitizing broad bean: a new stem nematode singled out from the Ditylenchus dipsaci species complex using a polyphasic approach with molecular phylogeny.plant pathology doi:10.1111/j.13653059.2011.02430.x. 